\title{
Transfer of the Illusion of Control Between two
} Gambling Tasks

C. Done and K.R. Coventry

\section{Q OpenEdition \\ 1 Journals}

Electronic version

URL: http://journals.openedition.org/cpl/242

DOI: $10.4000 / \mathrm{cpl} .242$

ISSN: $1379-6100$

Publisher

Centre PsyCLÉ

Printed version

Date of publication: 1 August 2000

\section{Electronic reference}

C. Done and K.R. Coventry, "Transfer of the Illusion of Control Between two Gambling Tasks », Current psychology letters [Online], 2000/2, 2 | 2000, Online since 17 September 2003, connection on 08

September 2020. URL : http://journals.openedition.org/cpl/242 ; DOI : https://doi.org/10.4000/cpl.242

This text was automatically generated on 8 September 2020.

(C) All rights reserved 


\title{
Transfer of the Illusion of Control Between two Gambling Tasks
}

\author{
C. Done and K.R. Coventry
}

